\title{
Leaf traits and gas exchange in saplings of native tree species in the Central Amazon
}

\author{
Keila Rego Mendes ${ }^{1}$; Ricardo Antonio Marenco ${ }^{2 *}$ \\ ${ }^{1}$ INPA/Instituto Nacional de Pesquisas da Amazônia - Programa de Pós-Graduação em Botânica. \\ ${ }^{2} I N P A$ - Coordenação de Pesquisas em Silvicultura Tropical, Av. André Araújo, 1756 - C.P. 478 - $69011-970$ - \\ Manaus, AM - Brasil. \\ *Corresponding author <rmarenco@inpa.gov.br>
}

\begin{abstract}
Global climate models predict changes on the length of the dry season in the Amazon which may affect tree physiology. The aims of this work were to determine the effect of the rainfall regime and fraction of sky visible (FSV) at the forest understory on leaf traits and gas exchange of ten rainforest tree species in the Central Amazon, Brazil. We also examined the relationship between specific leaf area (SLA), leaf thickness (LT), and leaf nitrogen content on photosynthetic parameters. Data were collected in January (rainy season) and August (dry season) of 2008. A diurnal pattern was observed for light saturated photosynthesis $\left(\mathrm{A}_{\max }\right)$ and stomatal conductance $\left(\mathrm{g}_{\mathrm{s}}\right)$, and irrespective of species, $\mathrm{A}_{\max }$ was lower in the dry season. However, no effect of the rainfall regime was observed on $\mathrm{g}_{\mathrm{s}}$ nor on the photosynthetic capacity $\left(\mathrm{A}_{\mathrm{pot}}\right.$, measured at saturating $\left.\left[\mathrm{CO}_{2}\right]\right) . \mathrm{A}_{\mathrm{pot}}$ and leaf thickness increased with FSV, the converse was true for the FSV-SLA relationship. Also, a positive relationship was observed between $\mathrm{A}_{\text {pot }}$ per unit leaf area and leaf nitrogen content, and between $\mathrm{A}_{\text {pot }}$ per unit mass and SLA. Although the rainfall regime only slightly affects soil moisture, photosynthetic traits seem to be responsive to rainfall-related environmental factors, which eventually lead to an effect on $\mathrm{A}_{\text {max. }}$ Finally, we report that little variation in FSV seems to affect leaf physiology $\left(\mathrm{A}_{\mathrm{pot}}\right)$ and leaf anatomy (leaf thickness).
\end{abstract}

Key words: diurnal variation, forest understory, photosynthetic capacity, rainfall seasonality

\section{Características foliares e trocas gasosas em arvoretas de espécies nativas da Amazônia Central}

\begin{abstract}
RESUMO: Os modelos climáticos globais prevêem mudanças na extensão da época seca na Amazônia, o que pode afetar a fisiologia das árvores. Os objetivos deste trabalho foram determinar o efeito da sazonalidade da precipitação e fração de céu visível (FSV) no sub-bosque da floresta nas características foliares e trocas gasosas de 10 espécies florestais da Amazônia Central. Também examinou-se a relação entre área foliar específica (SLA), espessura da folha (LT) e nitrogênio foliar em parâmetros fotossintéticos. Os resultados foram coletados nos meses de janeiro (época chuvosa) e agosto (época seca) de 2008. Observou-se um padrão de variação diurna na fotossíntese saturada por luz $\left(\mathrm{A}_{\max }\right)$ e na condutância estomática $\left(\mathrm{g}_{\mathrm{s}}\right)$. Independente da espécie, $\mathrm{A}_{\max }$ foi menor na época seca. No entanto, não houve efeito da sazonalidade das chuvas em $\mathrm{g}_{\mathrm{s}}$ nem na capacidade fotossintética ( $\mathrm{A}_{\mathrm{pot}}$ medida em $\left[\mathrm{CO}_{2}\right]$ saturante). $\mathrm{A}_{\mathrm{pot}}$ e a espessura da folha (LT) aumentaram com FSV, o contrário foi observado para a relação FSV-SLA. Também, observou-se uma relação positiva entre $\mathrm{A}_{\text {pot }}$ por unidade de área e conteúdo de nitrogênio foliar, e entre $\mathrm{A}_{\text {pot }}$, por unidade de massa e SLA. Embora o regime das chuvas apenas levemente influenciou a umidade do solo, características fotossintéticas parecem responderem a fatores relacionados com as chuvas, o que repercute $\mathrm{em} \mathrm{A}_{\max }$. Finalmente, relata-se que pequenas variações em FSV parecem afetar a fisiologia da folha $\left(A_{\text {pot }}\right)$ e a anatomia foliar (espessura da folha).

Palavras-chave: capacidade fotossintética, sub-bosque, variação diurna, sazonalidade das chuvas
\end{abstract}

\section{Introduction}

Global climate models predict that in the Amazon the length of the dry season period will be extended as a result of global warming associated to an increase of atmospheric $\mathrm{CO}_{2}$ concentration (Cox et al., 2004). Indeed, a prolonged dry period may affect plant growth and physiological processes, such as photosynthesis and respiration (Hughes, 2000). Although severe soil moisture depletion during prolonged drought may lead to stomatal closure and a decline in leaf area (Nepstad et al., 1994), there is still controversy on whether draught-in- duced water deficit limits tree growth in the Central Amazon. During the 2005 drought, for example, Saleska et al. (2007) reported an enhanced vegetation index of the forest based on moderate resolution imaging spectroradiometer (MODIS) satellite data. This is contrary to what should be expected, as changes in precipitation can alter growth rates (Lewis et al., 2004). In a rainfall exclusion experiment, a $60 \%$ reduction of incoming throughfall led to a drastic increase $(38 \%)$ in tree mortality (Nepstad et al., 2007), much higher than commonly recorded in the Central Amazon, about $1.1 \%$ per year (Williamson et al., 2000). Although sapling photosyn- 
thetic traits of canopy trees have received some attention in tropical forest (e.g. Marenco and Vieira, 2005; Poorter and Oberbauer, 1993), how seasonality of the rainfall regime affects seedling and sapling photosynthetic traits in the Central Amazon still remains to be elucidated.

In addition to soil moisture, light availability is one of the most important factors limiting seedling and sapling growth in the forest understory (Denslow et al., 1990; Valladares and Niinemets, 2008). Through the canopy profile light varies not only in total quantity, but also in quality, as the red/far red $(\mathrm{R} / \mathrm{Fr}$ ) ratio declines towards the forest floor (Smith, 1982). Low irradiance often leads to a decrease in leaf thickness and light saturated photosynthesis $\left(\mathrm{A}_{\max }\right)$, whereas specific leaf area (SLA) commonly increases under low light intensity (Oguchi et al., 2005). Plant growth is the result of a complex of interacting factors intrinsically related to carbon gain via photosynthesis and loss due to respiration. However, over a wide range of plants species and growth conditions there seems to be a positive relationship between plant growth and photosynthetic rates (Kruger and Volin, 2006)

In this study we hypothesized that variation in soil moisture and subtle changes in light availability in the forest understory affect leaf traits and carbon gain in saplings of canopy trees. Thus, the aims of this work were to determine the effect of the seasonal rainfall regime and understory irradiance on leaf traits and gas exchange in ten rainforest tree species. We also examined the effect of specific leaf area (SLA), leaf thickness (LT), and nitrogen content on the photosynthetic capacity.

\section{Material and Methods}

The study was conducted $60 \mathrm{~km}$ north of Manaus (02³6’21" S; 6008'11" W), state of Amazonas, Brazil, in an area of native "terra-firme" forest. The region has characteristics of a humid equatorial climate, with a short mild dry season (July-September, with a rainfall of $50-100 \mathrm{~mm}$ per month), and a dry-wet transition month (October). The wet season extends from Novem- ber to May (200-300 mm month $\left.{ }^{-1}\right)$. Annual precipitation is $2240 \mathrm{~mm}$ (Inmet, 2008, mean of 1961 to 1990). The area is covered by a dense forest and the predominant soil type is an Oxisol of low fertility, clay texture and $\mathrm{pH}$ of 4.2 to 4.5 .

We used saplings (1.5 to $2-\mathrm{m}$ tall) of 10 tree species selected taking into account their shade tolerance, relative abundance of saplings in the forest understory (at least three replications per species), and economic importance (Table 1). The gas exchange parameters were measured with an infrared gas analyzer (Li-6400, Li-Cor, NE, USA) using one or two leaves per plant and three saplings per species on each season. Light saturated photosynthesis $\left(\mathrm{A}_{\max }\right)$ was measured at ambient $\mathrm{CO}_{2}$ concentration $\left(380 \mu \mathrm{mol} \mathrm{mol}{ }^{-1}\right)$, light saturation $\left(1000 \mu \mathrm{mol} \mathrm{m}{ }^{-2}\right.$ $\mathrm{s}^{-1}$, and ambient temperature $\left(28 \pm 1^{\circ} \mathrm{C}\right)$. Potential photosynthesis $\left(\mathrm{A}_{\mathrm{pot}}\right.$, hereafter termed photosynthetic capacity) was also measured at light saturation, but at a $\left[\mathrm{CO}_{2}\right]$ of $2000 \mu \mathrm{mol} \mathrm{mol}^{-1}$, rather than ambient $\left[\mathrm{CO}_{2}\right]$. Gas exchange data were collected after a stabilization period of about 10-15 min (total coefficient of variation $<0.7 \%$ ). The effect of the time of day on stomatal conductance $\left(\mathrm{g}_{\mathrm{s}}\right)$ and $\mathrm{A}_{\max }$ was assessed across species by collecting data between 06 h00 and 18h00. Data were collected in January and August 2008 in mature and fully expanded leaves.

Specific leaf area (SLA, the leaf area to leaf mass ratio) was determined in both seasons. As additional information, leaf thickness was determined in the dry season and leaf nitrogen content in the wet season. We measured SLA in a sample of six circles of $240-\mathrm{mm}^{2}$ - per leaf obtained from a sample of two to eight leaves per plant, depending on leaf size. We only determined nitrogen (Kjeldahl method) in the wet season (first studied season) in order to preserve the foliage for further studies in the same area. Fresh leaf thickness (FLT) and dry leaf thickness (DLT) were measured with digital calipers in 240- $\mathrm{mm}^{2}$-leaf circles (two per leaf) punched from the widest part of the leaf blade, and between the major veins (accuracy of $10 \mu \mathrm{m}$ ). Leaves used for SLA, leaf nitrogen and leaf thickness measurements were the same or similar in appearance (when more than two leaves were re-

Table 1 - Families and importance of the species.

\begin{tabular}{lcc}
\hline Species & Family & Importance \\
\hline Chimarrhis duckeana del Prete & Rubiaceae & Silvicultural system \\
Ecclinusa guianensis Eyma & Sapotacea & Silvicultural system \\
Erythroxylum amplum Bth. & Erythroxylaceae & Silvicultural system \\
Licania oblongifolia Standl. & Chrysobalanaceae & Timber industry \\
Pouteria guianensis Aubl. & Sapotaceae & Timber industry \\
Rinorea racemosa (Mart. et Zucc.) O. Ktz. & Violaceae & Silvicultural system \\
Sorocea guilleminiana Gaudich. & Moraceae & Pharmacological potential \\
Tetragastris unifoliolata (Engl.) Cuatr. & Burseraceae & Silvicultural system \\
Virola calophylla (Spruce) Warb. & Myristicaceae & Pharmacological potential \\
Zygia juruana (Harms) L. Rico & Fabaceae & Silvicultural system \\
\hline
\end{tabular}


quired for analysis) to those used for gas exchange determinations. Leaf dry mass was obtained after leaf dehydration at $72^{\circ} \mathrm{C}$ until constant mass. The fraction of sky visible (FSV) beneath the canopy was measured using a canopy analyzer (LAI-2000, Li-Cor, NE, USA), under overcast sky conditions to improve the accuracy of the instrument, and calculated by integrating the gap fraction to yield the fraction of sky not blocked by foliage. For each sapling, six FSV readings, collected at a distance of about $1.5 \mathrm{~m}$ from the stem and forming a circle around the plant (the microsite), were recorded at each microsite and a mean value was obtained. The height of the sensor above the ground corresponded to the height of leaves used for the gas exchange measurements (1 to $2 \mathrm{~m}$ above the ground). Finally, we used a second LAI2000 sensor, operating in the remote mode and installed on the top of a $40-\mathrm{m}$-tall observation tower (located in a nearby area), to log FSV values above the forest canopy.

Irradiance and rainfall data were recorded above the forest canopy at the top of the 40-m tall observation tower. Irradiance at the observation tower $\left(\mathrm{I}_{\text {open }}\right)$ was measured using a quantum sensor (Li-190 SA, Li-Cor, NE, USA). Understory irradiance $\left(\mathrm{I}_{\text {und }}\right)$ was estimated as the product of FSV by $I_{\text {open }}$ (i.e. $I_{\text {und }}^{\text {und }}=$ FSV x $I_{\text {open }}$ ). We are aware that $I_{\text {und }}$ is lower than the actual light availability at sapling height, as it does not take into account the background of diffuse light in the forest understory (about 5-8 $\mu \mathrm{mol} \mathrm{m}^{-2} \mathrm{~s}^{-1}$ at midday (Marenco and Vieira, 2005). Temperature and air humidity data were recorded at 30-min-intervals with a sensor (Humitter 50y, Vaisala Oy, Finland) connected to a datalogger (Li-1400, Li-Cor, NE, USA) at a selected site in the understory. In addition, an external quantum sensor (Li-190 SA, Li-Cor, USA) mounted on the Li-6400's irga head was used to log irradiance data at the same time as gas exchange measurements were made. Both in the dry and rainy season, soil moisture was determined gravimetrically: $100\left(S_{w}-S_{d}\right) / S_{w}$, where $S_{w}$ and $S_{d}$ represent the mass of wet and dry, undisturbed $110-\mathrm{cm}^{3}-$ soil samples. Soil samples were collected at random in the study area at the depth of $200 \mathrm{~mm}$, both in the wet
(26 samples) and dry season (12 samples). All data, but leaf thickness and $\mathrm{N}$ content (determined only in one season), were subjected to analysis of variance (ANOVA) to assess the effect of the rainfall seasonality on the parameters. The Lilliefors test was conducted to assess whether experimental errors were normally distributed. As no transformation was needed, all statistical analyses were carried out on untransformed data. When the effect of rainfall seasonality on the variables was not significant $(p>0.05)$, data were pooled and linear or quadratic regression analyses conducted to examine the effect of FSV and SLA on photosynthetic traits. Tukey post-hoc test was used for mean separation $(p \leq 0.05)$.

\section{Results and Discussion}

Monthly rainfall was $353 \mathrm{~mm}$ in January and $105 \mathrm{~mm}$ in August (Table 2), which is in accordance with the historical mean (1961-1990) for the region (Inmet, 2008). In these months, soil moisture ranged between $31 \%$ in the dry season to $32 \%$ in the wet season, near the soil saturation point of $39 \%$ on a wet soil basis (Table 2). Air temperature at the forest floor ranged from $22^{\circ} \mathrm{C}$ at night to $29^{\circ} \mathrm{C}$ at noon, and for most of the day the relative humidity was above $90 \%$, with no difference between seasons (Figure 1). Accumulated irradiance at the forest floor was 0.3 and $0.6 \mathrm{~mol} \mathrm{~m}^{-2} \mathrm{day}^{-1}$ in the wet and dry seasons, respectively. On the other hand, mean maximum understory irradiance was about 10 and $20 \mu \mathrm{mol}$ $\mathrm{m}^{-2} \mathrm{~s}^{-1}$ for the wet and dry seasons, respectively, or about $1.5-2 \%$ of the irradiance recorded above the forest canopy (Figure 1). $I_{\text {und }}$ values reported in this study are a somewhat higher than those observed by others (Kursar and Coley, 1999; Marenco and Vieira, 2005), perhaps because our $\mathrm{I}_{\text {und }}$ values were recorded about 1-2 $\mathrm{m}$ above the ground rather than at the forest floor. Molion (1987) estimated that the irradiance that reaches the forest floor is $1.2 \%$ (approximately $14 \mu \mathrm{mol} \mathrm{m}{ }^{-2} \mathrm{~s}^{-1}$ on a sunny day) of that received above the forest canopy, similar to our $I_{\text {und }}$ values observed in the wet season.

Table 2 - Light saturated photosynthesis $\left(\mathrm{A}_{\max }\right)($ mean $\pm \mathrm{SE})$, photosynthetic capacity $\left(\mathrm{A}_{\mathrm{pot}}\right)$, fraction of sky visible (FSV), stomatal conductance $(\mathrm{g})$ ), leaf area index, photosynthetic photon flux density (PFD) above the forest canopy, rainfall and soil moisture observed in January (rainy season) and August (dry season) of 2008.

\begin{tabular}{|c|c|c|}
\hline Parameter & January & August \\
\hline $\mathrm{A}_{\max }\left(\mu \mathrm{mol} \mathrm{m} \mathrm{m}^{-2} \mathrm{~s}^{-1}\right)$ & $3.3 \pm 0.3 \mathrm{a}$ & $2.5 \pm 0.2 b$ \\
\hline $\mathrm{A}_{\mathrm{pot}}\left(\mu \mathrm{mol} \mathrm{m} \mathrm{m}^{-2} \mathrm{~s}^{-1}\right)$ & $8.04 \pm 0.24 \mathrm{a}$ & $8.66 \pm 0.31 \mathrm{a}$ \\
\hline FSV (unitless) & $0.014 \pm 0.001 b$ & $0.020 \pm 0.001 a$ \\
\hline $\mathrm{g}_{\mathrm{s}}\left(\mathrm{mol} \mathrm{m}^{-2} \mathrm{~s}^{-1}\right)$ & $0.1 \pm 0.01 \mathrm{a}$ & $0.1 \pm 0.01 \mathrm{a}$ \\
\hline Leaf area index (unitless) & $5.1 \pm 0.05 a$ & $4.7 \pm 0.06 b$ \\
\hline PFD $\left(\mathrm{mol} \mathrm{m}^{-2}\right.$ day $\left.^{-1}\right)$ & $20.83 \pm 1.2 b$ & $31.52 \pm 1.0 \mathrm{a}$ \\
\hline${ }^{1}$ Rainfall (mm) & 353 & 105 \\
\hline Soil moisture (\%) & $32 \pm 0.6 \% \mathrm{a}$ & $31 \pm 0.4 \%$ a \\
\hline
\end{tabular}

${ }^{1}$ Value measured in January and August (one data, no SE). Means followed by the same letters within rows do not differ according to Tukey test at $5 \%$ probability. 
Early in the morning and late in the afternoon stomata did not respond to light stimulus, remaining closed even at saturating irradiance $\left(1000 \mu \mathrm{mol} \mathrm{m}^{-2} \mathrm{~s}^{-1}\right)$ for photosynthesis in the leaf chamber (Figure 2). Stomata closed and $\mathrm{A}_{\max }$ declined as the vapor pressure deficit (VPD) increased (Figure 3). However, as the forest understory became brighter, $\mathrm{A}_{\max }$ and $\mathrm{g}_{\mathrm{s}}$ tended to linearly increase with irradiance (Figure 4), which indicates that in this environment $g_{s}$ and $A_{\max }$ are under the influence of a diurnal cycle, perhaps affected by light and VPD (Figures 3, 4). Our results agree with those reported by Kaiser and Kappen (2000) who observed maximum gs values between $10 \mathrm{~h} 00$ and $14 \mathrm{~h} 00$ and a minimum stomatal aperture at sunset.

Light induces stomatal opening (Shimazaki et al., 2007) and thus stomata may open at irradiances above 2-8 $\mu \mathrm{mol} \mathrm{m} \mathrm{m}^{-2}$ (Habermann, 1973). However, soon after dawn light was ineffective in triggering stomatal opening. Since irradiance, relative humidity and temperature changed during daytime on the forest floor (Figure 1), it is possible that somehow these environmental factors affected stomatal functioning during the day. Although the light environment had an effect on $g_{s}(p<0.05$, Figure $4 \mathrm{~B})$, the correlation between $\mathrm{g}_{\mathrm{s}}$ and irradiance at mea-

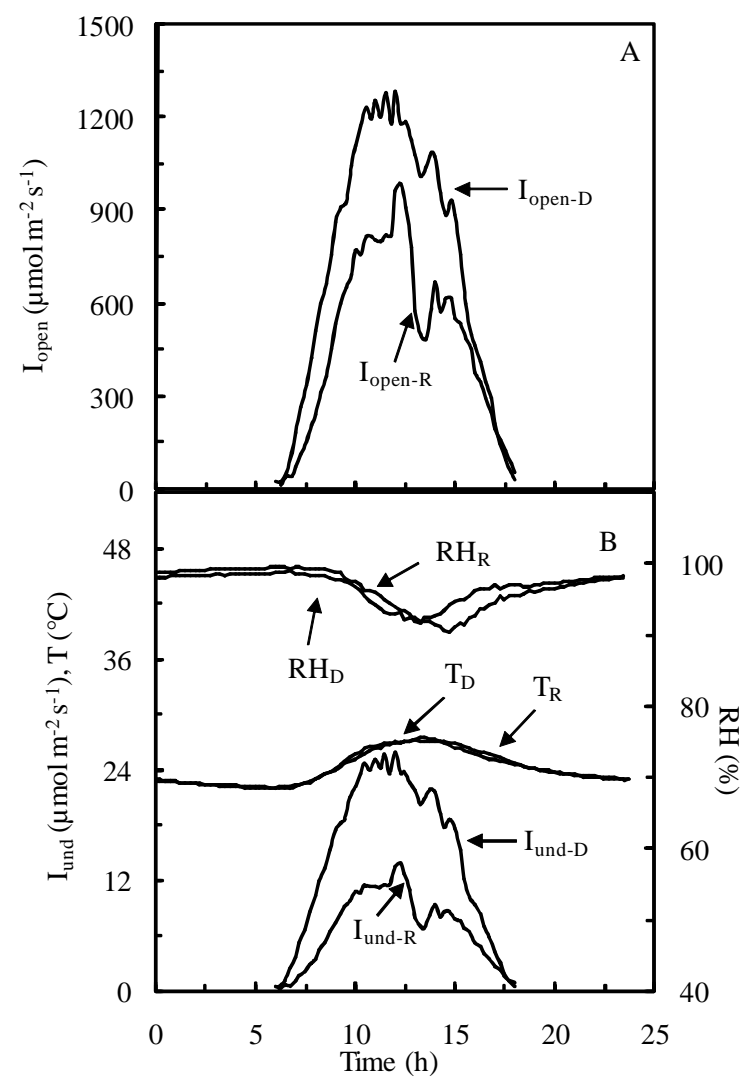

Figure 1 - Diurnal irradiance above the forest canopy (A, $\left.\mathrm{I}_{\text {open }}\right)$, and relative humidity $(\mathrm{RH})$, temperature $(\mathrm{T})$ and irradiance at the forest understory $\left(\mathrm{B}, \mathrm{I}_{\text {und }}\right)$. Data were collected in January (rainy season, $\mathrm{R}$ ) and August (dry season, D) of 2008. suring time was tenuous $\left(\mathrm{r}^{2}=0.05 \%\right)$ VPD has an important effect on $\mathrm{g}_{\mathrm{s}}$, but it only explains $24 \%$ of variation (Figure 3B). Thus, we cannot rule out the effect of endogenous factors in modulating stomatal functioning, as reported by others, both in herbaceous plants (Gorton et al., 1993; Holmes and Klein, 1986) and forest trees (Doughty et al., 2006).

Although there was no difference in soil moisture between the dry and rainy season, $\mathrm{A}_{\max }$ was lower in the dry season (Table 2), which suggests that even a slight decline in soil moisture, or perhaps in leaf water potential associated to a higher irradiance in the dry period, may affect some photosynthetic traits of understory saplings, perhaps mesophyll conductance $\left(\mathrm{g}_{\mathrm{m}}\right)$. Under progressive drought $\mathrm{g}_{\mathrm{m}}$ may decline (Flexas et al., 2002). This hypothesis is consistent with the fact that both $\mathrm{A}_{\text {pot }}$ and $\mathrm{g}_{\mathrm{s}}$ were unaffected by rainfall seasonality. As $\mathrm{g}_{\mathrm{s}}$ was not influenced by rainfall seasonality (Table 2), differences in $A_{\max }$ between seasons may be ascribed to a limitation of carbon uptake imposed by non-stomatal factors. Had the dry season had any detrimental effect on Rubisco

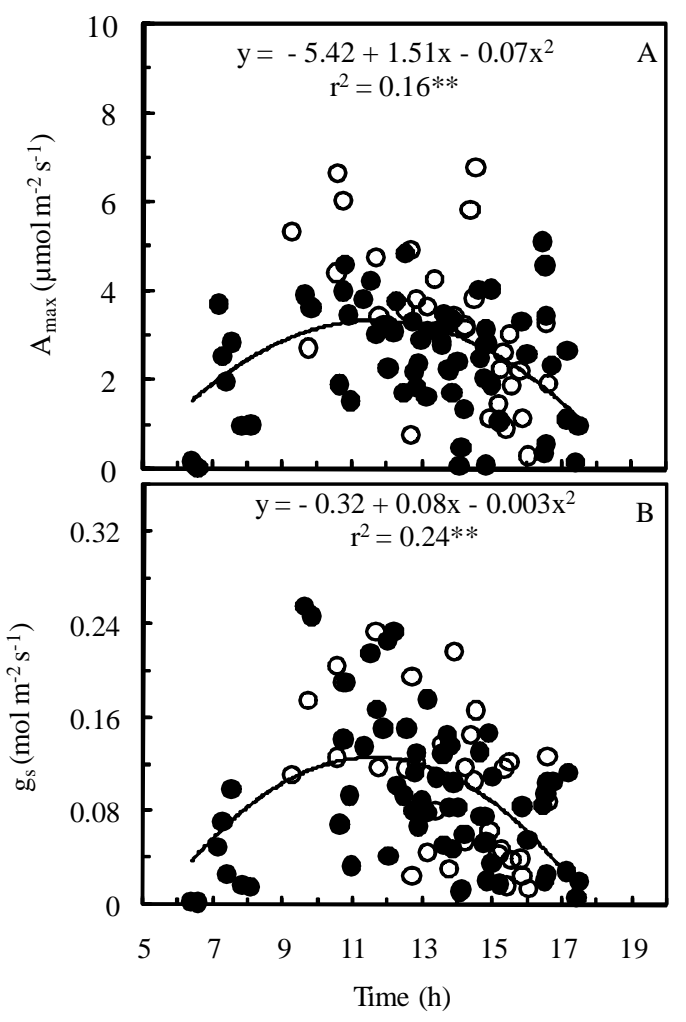

Figure 2 - Diurnal variation in light saturated photosynthesis $\left(\mathrm{A}, \mathrm{A}_{\max }\right)$, stomatal conductance $\left(\mathrm{B}, \mathrm{g}_{\mathrm{s}}\right)$ in January (rainy season, open circle, $\mathrm{O}$ ) and August (dry season, closed circle, •) of 2008 in saplings of 10 forest tree species of the Central Amazon. Each symbol represents one leaf (one or two leaves per plant). Measurements were made at a $\left[\mathrm{CO}_{2}\right]$ of $380 \mu \mathrm{mol}$ $\mathrm{mol}^{-1}$, irradiance of $1000 \mu \mathrm{mol} \mathrm{m} \mathrm{m}^{-2} \mathrm{~s}^{-1}$ and leaf temperature of $28 \pm 1^{\circ} \mathrm{C}$. The continuous line shows the trend observed throughout the day. **significant at $p<0.01$. 


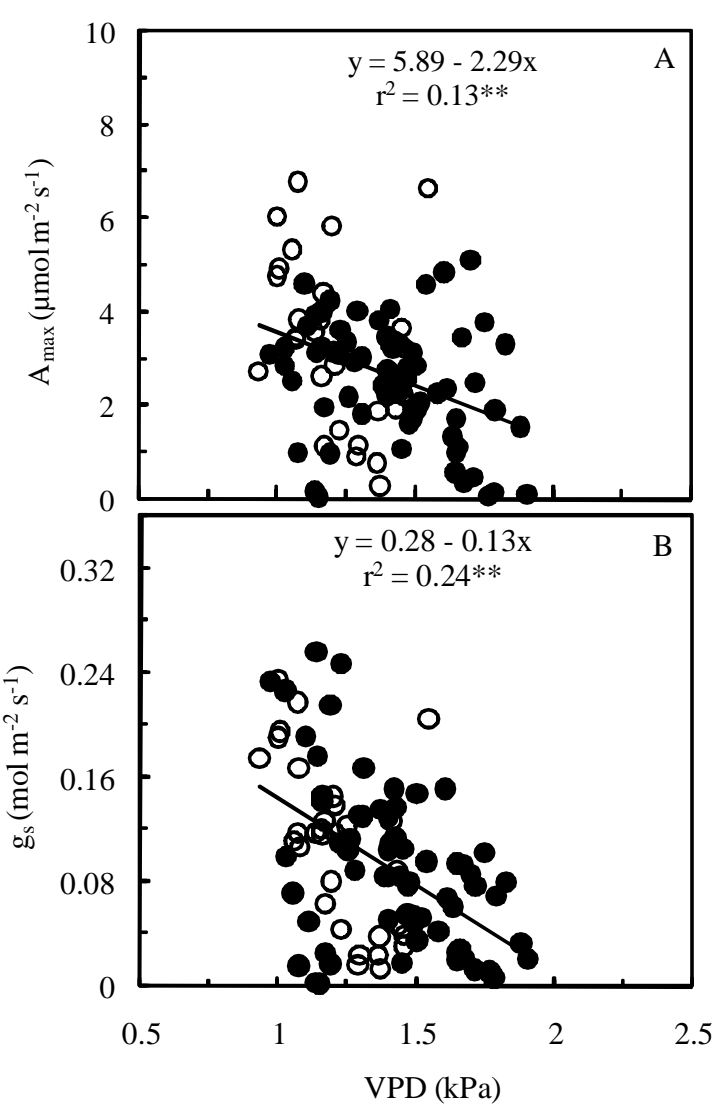

Figure 3 - Relationship between light saturated photosynthesis $\left(\mathrm{A}, \mathrm{A}_{\max }\right)$ and stomatal conductance $\left(\mathrm{B}, \mathrm{g}_{\mathrm{s}}\right)$ and vapor pressure deficit (VPD), in January (rainy season, open circle, $\bigcirc$ ) and August (dry season, closed circle, $\bullet$ ) of 2008 in saplings of 10 forest tree species of the Central Amazon. Each symbol represents one leaf (one or two leaves per plant). Experimental conditions as described in Figure 2. **significant at $p<0.01$. activity or ATP synthesis (Flexas and Medrano, 2002) $A_{\text {pot }}$ should have declined, but it did not. This allows us to conclude that the seasonality may have an effect on $g_{m}$. In relation to the seasonal effect on $A_{\max }$ is important to take into account that climate models predict changes in the total rainfall in the Amazon as a result of global warming (Cox et al. 2004; Oyama and Nobre, 2003). Besides, differences among species were not observed in $\mathrm{A}_{\max }$ nor in $\mathrm{A}_{\text {pot }}$, so data from both rainfall seasons were pooled to obtain a mean value for each species (Table 3).

At ambient $\mathrm{CO}_{2}$ concentration $\left(380 \mu \mathrm{mol} \mathrm{mol}^{-1}\right), \mathrm{A}_{\max }$ was closely related with $g_{\mathrm{s}}\left(r^{2}=0.60 \%\right.$, Figure $\left.5 \mathrm{~A}\right)$, which is consistent with results reported by others (Machado et al., 2002; Marenco et al., 2006; Park and Furukawa, 1999). Nonetheless, the correlation between $A_{p o t}$ and $g_{s}$ was very low $\left(\mathrm{r}^{2}=0.01^{\mathrm{ns}}\right)$ at saturating $\mathrm{CO}_{2}$ concentration (Figure $5 \mathrm{~B}$ ), indicating that $\mathrm{A}_{\text {pot }}$ is little influenced by stomatal opening in the $g_{s}$ range observed for most of the day (08h00 to 16h00). Except very early in the morning, when most stomata were closed, their resistance to $\mathrm{CO}_{2}$ diffusion into intercellular spaces was offset by an elevated $\mathrm{CO}_{2}$ concentration in the leaf chamber. However, when $g_{s}$ was very low (less than $0.015 \mathrm{~mol}$ $\mathrm{m}^{-2} \mathrm{~s}^{-1}$, denoted by diamonds in Figure $5 \mathrm{~B}$ ) the resistance imposed by stomatal closure was not compensated by a high $\mathrm{CO}_{2}$ concentration in the leaf chamber, which led to a reduction in photosynthetic capacity. Thus, a $g_{s}$ of $0.015 \mathrm{~mol} \mathrm{~m}^{-2} \mathrm{~s}^{-1}$ most likely reflects a threshold below which leaf conductance is mainly due to cuticular conductance $\left(\mathrm{g}_{\mathrm{c}}\right)$. Because $\mathrm{A}_{\text {pot }}$ remained quite constant for most of the day, the effect of FSV, SLA, LT and leaf nitrogen on photosynthetic rates were examined with respect to $A_{\text {pot }}$ rather that $A_{\max }$, which was strongly dependent on $g_{s}$. FSV was positively related to leaf thickness

Table 3 - Light saturated photosynthesis $\left(\mathrm{A}_{\max }\right)$, photosynthetic capacity $\left(\mathrm{A}_{\mathrm{pot}}\right)$, specific leaf area (SLA), fresh leaf thickness (FLT), dry leaf thickness (DLT), and leaf nitrogen content determined in saplings of native tree species of the Central Amazon. Each value represents the mean of two seasons ( $A_{\max }, A_{p o t}$ and SLA) or one season (leaf thickness and leaf nitrogen).

\begin{tabular}{|c|c|c|c|c|c|c|}
\hline Species & $\mathrm{A}_{\max }$ & $A_{\text {pot }}$ & SLA & FLT & DLT & Leaf nitrogen \\
\hline & \multicolumn{2}{|c|}{$\mu \mathrm{mol} \mathrm{m}{ }^{-2} \mathrm{~s}^{-1}$} & $\mathrm{~m}^{2} \mathrm{~kg}^{-1}$ & \multicolumn{2}{|c|}{ mm n-m m } & $\mathrm{g} \mathrm{m}^{-2}$ \\
\hline C. duckeana & $2.9 \mathrm{a}$ & $8.0 \mathrm{a}$ & $16.3 \mathrm{bc}$ & $0.23 \mathrm{a}$ & $0.18 \mathrm{a}$ & $1.3 \mathrm{bc}$ \\
\hline E. guianensis & $3.6 \mathrm{a}$ & $8.3 \mathrm{a}$ & $14.2 \mathrm{c}$ & $0.18 \mathrm{~cd}$ & $0.13 \mathrm{bc}$ & $1.4 \mathrm{ab}$ \\
\hline E. amplum & $4.2 \mathrm{a}$ & $9.6 \mathrm{a}$ & $19.0 \mathrm{ab}$ & $0.22 \mathrm{ab}$ & $0.16 \mathrm{ab}$ & $1.1 \mathrm{bcd}$ \\
\hline L. oblongifolia & $2.7 \mathrm{a}$ & $7.1 \mathrm{a}$ & $15.3 \mathrm{bc}$ & $0.23 a$ & $0.16 \mathrm{ab}$ & $1.2 \mathrm{bcd}$ \\
\hline P. guianensis & $3.5 \mathrm{a}$ & $8.8 \mathrm{a}$ & $16.9 \mathrm{abc}$ & $0.15 \mathrm{~d}$ & $0.11 \mathrm{c}$ & $1.0 \mathrm{~cd}$ \\
\hline R. racemosa & $2.7 \mathrm{a}$ & $8.0 \mathrm{a}$ & $20.8 \mathrm{a}$ & $0.21 \mathrm{ab}$ & $0.15 \mathrm{ab}$ & $0.9 \mathrm{~cd}$ \\
\hline S. guilleminiana & $2.0 \mathrm{a}$ & $8.6 \mathrm{a}$ & $13.5 \mathrm{c}$ & $0.20 \mathrm{abc}$ & $0.15 \mathrm{ab}$ & $1.7 \mathrm{a}$ \\
\hline T. unifoliolata & $2.3 \mathrm{a}$ & $8.1 \mathrm{a}$ & $18.7 \mathrm{ab}$ & $0.16 \mathrm{~cd}$ & $0.11 \mathrm{c}$ & $0.9 \mathrm{~d}$ \\
\hline V. calopbylla & $2.5 \mathrm{a}$ & $8.1 \mathrm{a}$ & $15.9 \mathrm{bc}$ & $0.16 \mathrm{~cd}$ & $0.13 \mathrm{bc}$ & $1.2 \mathrm{bc}$ \\
\hline Z. juruana & $2.9 \mathrm{a}$ & $8.7 \mathrm{a}$ & $15.4 \mathrm{bc}$ & $0.17 \mathrm{bcd}$ & $0.12 \mathrm{bc}$ & $1.3 \mathrm{bc}$ \\
\hline Mean & 3.3 & 8.3 & 16.6 & 0.19 & 0.14 & 1.2 \\
\hline CV (\%) & 22.9 & 51.5 & 17.8 & 14.0 & 20.8 & 20.0 \\
\hline
\end{tabular}

Means followed by the same letters within columns do not differ according to Tukey test at $5 \%$ probability. 


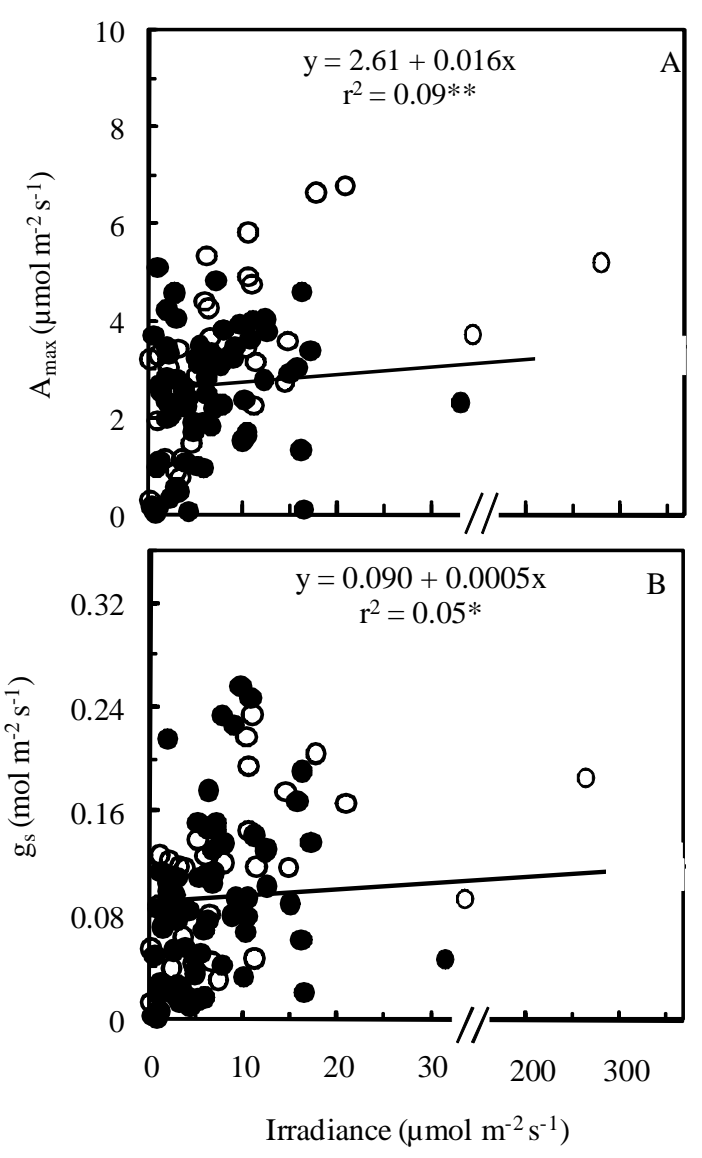

Figure 4 - Relationship between light saturated photosynthesis $\left(\mathrm{A}, \mathrm{A}_{\max }\right)$ and stomatal conductance $\left(\mathrm{B}, \mathrm{g}_{\mathrm{s}}\right)$ and instantaneous irradiance recorded at the forest understory during gas exchange measurements, in January (rainy season, open circle, $\mathrm{O}$ ) and August (dry season, closed circle, $\bullet$ ) of 2008 in saplings of 10 forest tree species of the Central Amazon. Each symbol represents one leaf (one or two leaves per plant). Experimental conditions as described in Figure 2. *significant at $p<0.05 ; * *$ significant at $p<0.01$.

(Figures 6A, B) and $\mathrm{A}_{\mathrm{pot}}$ (Figure 6C), whereas its relationship with SLA was negative (Figure 6D). DLT ranged from $0.11 \mathrm{~mm}$ in P. guianensis and T. unifoliolata to 0.18 $\mathrm{mm}$ in C. duckeana (Table 3), with an increase of about $35 \%$ in fresh leaves (Table 3 ), in both cases, a positive correlation between leaf thickness and $\mathrm{A}_{\mathrm{pot}}$ was found (Figure 7).

The effect of FSV on $A_{\text {pot }}$, LT and SLA shows that even small changes in intensity of light in the forest floor can alter the performance of the photosynthetic apparatus. This is in agreement with results reported by others (Ellsworth and Reich, 1993; Oguchi et al., 2005; Weston et al., 2000), who observed increases in LT in leaves exposed to brighter environments. The relationship between LT and $A_{\text {pot }}$ concurs with previous findings (McMillen and McClendon, 1983; Niinemets, 1999; Reich et al., 1998). Even when $A_{\text {pot }}$ and LT and SLA were strongly related (Figures 7,8 ), we cannot attribute increases in $\mathrm{A}_{\mathrm{pot}}$ only to variations in LT or SLA, as pho-

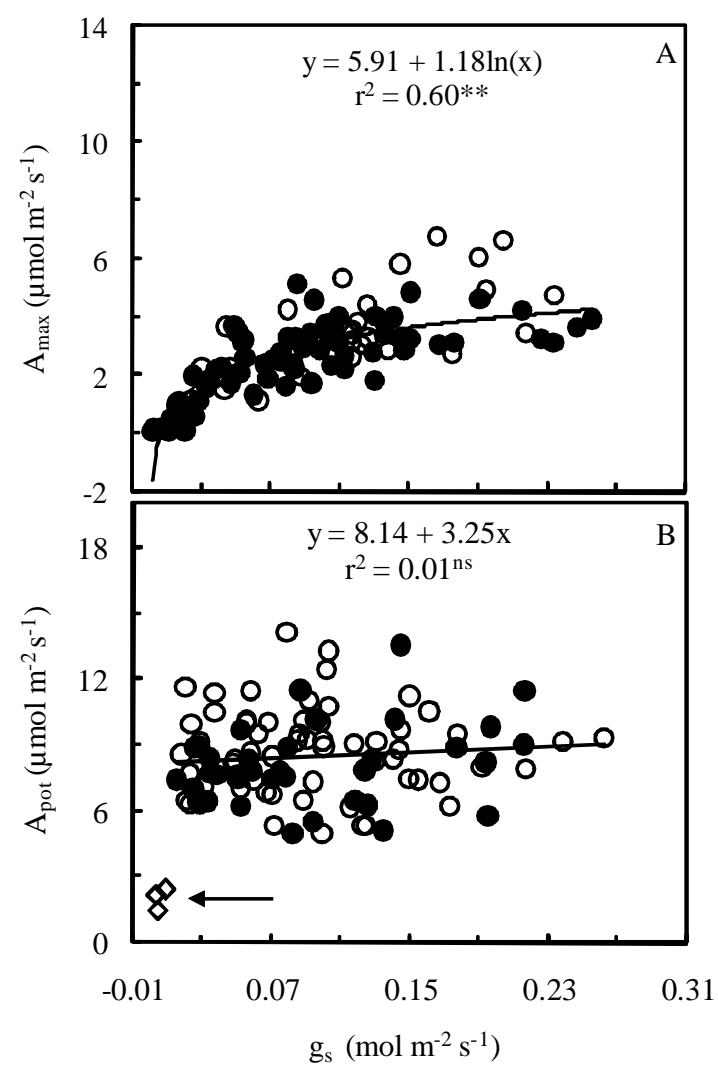

Figure 5 - Relationship between light saturated photosynthesis $\left(\mathrm{A}, \mathrm{A}_{\max }\right)$ and photosynthetic capacity $\left(\mathrm{B}, \mathrm{A}_{\mathrm{pot}}\right)$ and stomatal conductance $(\mathrm{g})$ in January (rainy season, open circle, $\mathrm{O}$ ) and August (dry season, closed circle, -) of 2008 in saplings of ten native forest tree species of the Central Amazon. $\mathrm{A}_{\mathrm{pot}}$ was measured at a $\left[\mathrm{CO}_{2}\right]$ of $2000 \mu \mathrm{mol} \mathrm{mol}^{-1}$ and saturating light. Other experimental conditions as described in Figure 2. The diamonds $(\diamond)$ in Figure $5 \mathrm{~B}$ show the values of $\mathrm{A}_{\mathrm{pot}}$ soon after dawn, when $\mathrm{g}_{\mathrm{s}}$ was very low. Each symbol represents one leaf (one or two leaves per plant). ns: not significant $(p>0.05)$, **significant at $p<0.01$.

tosynthetic compounds are less effectively used in thicker leaves, perhaps because of a lower leaf conductance in these leaves (Niinemets, 1999).

FSV values increased from 0.014 in January (rainy season) to 0.020 in August (dry season) (Table 2), confirming results obtained previously by Marenco and Vieira (2005). We attributed the difference in FSV values between the evaluated rainfall seasons to differences in leaf area index between the rainy and dry season (5.1 versus 4.7, Table 2) or to the higher solar radiation recorded in the dry season (Table 2). High irradiance in the dry season can result in greater carbon assimilation during this part of the year as suggested by Huete et al. (2006). However, a higher light intensity in the forest canopy in the dry season apparently does not contribute to increase the photosynthetic capacity of saplings at the forest floor, although across species, we found an effect of FSV on $A_{\text {pot }}$ irrespective of the seasonal rainfall regime, perhaps due to an effect of the $\mathrm{R} / \mathrm{Fr}$ ratio on 


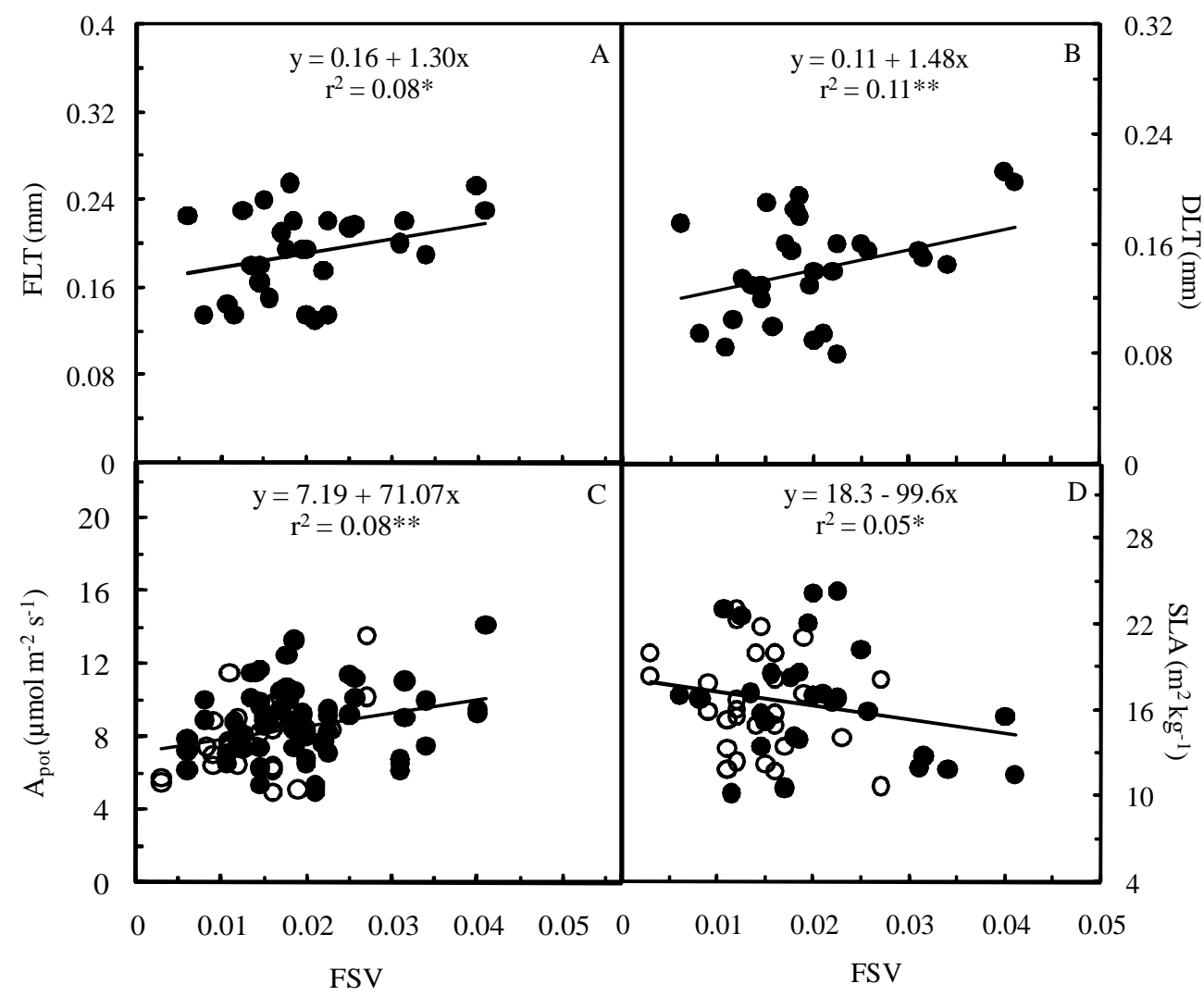

Figure 6 - Fresh (A, FLT) and dry leaf thickness (B, DLT), photosynthetic capacity (C, $\mathrm{A}_{\text {pot }}$ ) and specific leaf area (D, SLA) as a function of the fraction of sky visible (FSV) in January (rainy season, open circle, $O$ ) and August (dry season, closed circle, $\bullet$ ) of 2008 in saplings of ten forest tree species of the Central Amazon. Experimental conditions as described in Figure 5. Each symbol represents one leaf (one or two leaves per plant). *significant at $p<0.05$; **significant at $p<0.01$

photosynthetic rates. For Acmena ingens, for example, under low irradiance ( $\leq 20 \%$ of full sunlight) $\mathrm{g}_{\mathrm{s}}$ and $\mathrm{A}_{\max }$ where lower in plants grown under a reduced $\mathrm{R} / \mathrm{Fr}$ ratio (0.2) than in control plants $(\mathrm{R} / \mathrm{Fr}$ of sunlight, 1.2) (Turnbull, 1991).

SLA ranged from $13.5 \mathrm{~m}^{2} \mathrm{~kg}^{-1}$ in S. guilleminiana to $20.8 \mathrm{~m}^{2} \mathrm{~kg}^{-1}$ in $R$. racemosa, whereas the leaf nitrogen content varied between $0.9 \mathrm{~g} \mathrm{~m}^{-2}$ for T. unifoliolata and $R$. racemosa to $1.7 \mathrm{~g} \mathrm{~m}^{-2}$ for S. guilleminiana (Table 3). SLA values found in this study are within the range (15 and $24 \mathrm{~m}^{2} \mathrm{~kg}^{-1}$ ) observed by Marenco and Vieira (2005) for saplings of canopy tree species. FSV had a positive effect on LT, and a negative one on SLA $(p<0.05)$. The positive effect of leaf nitrogen on $A_{\text {pot }}$ (Figure 9) is consistent with the results reported by Hikosaka (2004; 2005). However, although significant, the relationship between $\mathrm{A}_{\text {pot }}$ and leaf $\mathrm{N}$ was weak $\left(\mathrm{r}^{2}=0.14, p<0.05\right)$ (Figure 9), indicating that a substantial fraction of the leaf nitrogen is partitioned into non-photosynthetic structures. On the other hand, differences in determination coefficients $\left(\mathrm{r}^{2}\right)$ between DLT and SLA against FSV $(0.11 * *$ versus $0.05 *$ for SLA, Figure $6 \mathrm{~B}, \mathrm{D})$ occur because SLA depends not only on LT, but also on leaf density (Niinemets, 1999), which suggests that FSV has a lower effect on leaf density. Although LT is affected by growth irradiance, we can not explain the wide variations in SLA among species only by differences in microsite brightness (inferred by FSV values) at the forest floor. This suggests that the genetic background of each species plays a major role in determining adaptive strategies to the physical and ecological environment (soil fertility and acidity, herbivory, etc.), which thereby leads to changes in LT and SLA under a given growth conditions (Lee et al., 2000; Peeters, 2002). Increase in LT (decline in SLA) is often related to higher photosynthetic rates per unit leaf area (McMillen and McClendon, 1983; Yun and Taylor, 1986), because of a greater accumulation of photosynthetic proteins. However, it may also involve an increase in the amount of molecules and compounds not directly related to carbon assimilation but with a key role for plant defense against herbivory and for increasing resistance against other physical hazards (Coley, 1988; Wright and Cannon, 2001).

Although the rainfall regime only slightly affected soil moisture, some photosynthetic traits (perhaps $\mathrm{g}_{\mathrm{m}}$ ) seem to be responsive to rainfall-related environmental attributes, which eventually lead to an effect on $A_{\max }$. In the forest understory, $A_{\max }$ and $g_{s}$ of saplings appear to be highly sensitive to diurnal variation, and even when stomatal functioning is affected by environment factors (e.g., light and VPD), somehow endogenous factors also seem to have a role in stomatal movements. However, 


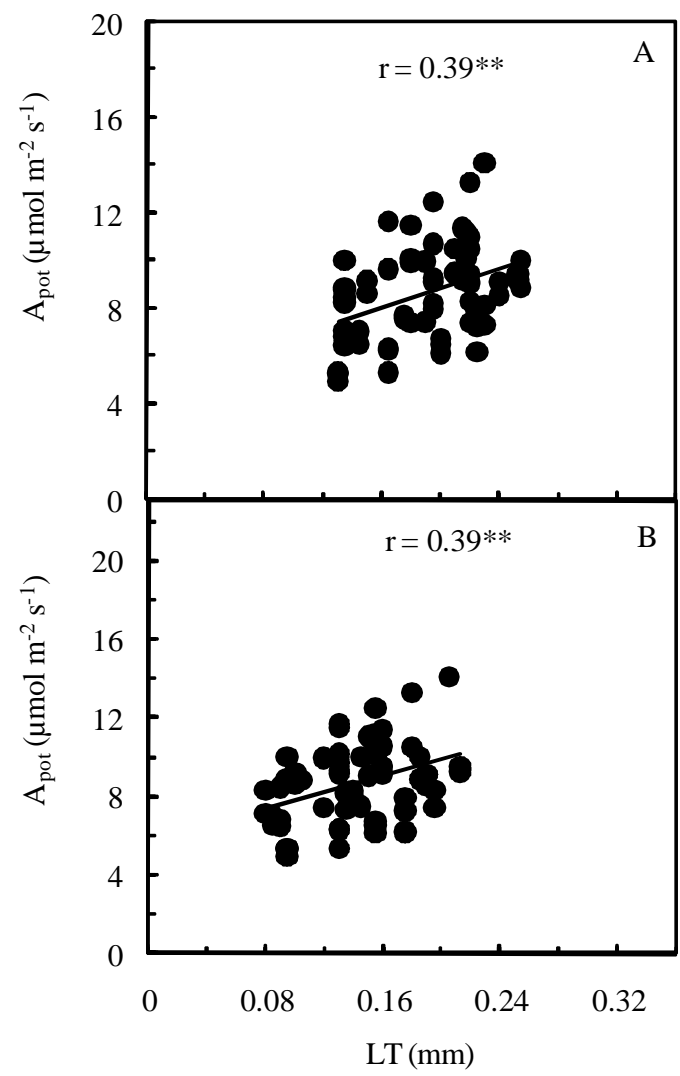

Figure 7 - Relationship between photosynthetic capacity $\left(\mathrm{A}_{\mathrm{pot}}\right)$ and fresh leaf thickness (A, FLT) and dry leaf thickness (B, DLT) in August (dry season) of 2008 in saplings of ten forest tree species of the Central Amazon. Experimental conditions as described in Figure 5. Each symbol represents one leaf (one or two leaves per plant). $*$ significant at $p<0.01$.

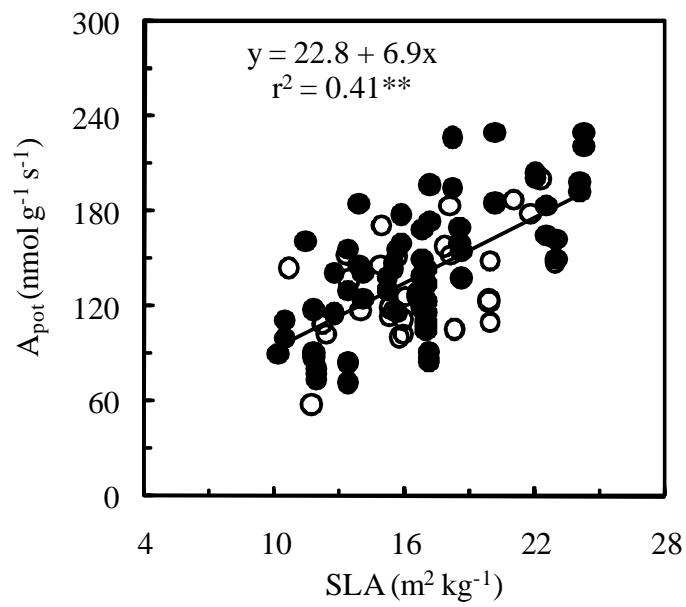

Figure 8 - Relationship between photosynthetic capacity $\left(\mathrm{A}_{\mathrm{pot}}\right)$ and specific leaf area (SLA) in January (wet season, open circle, O) and August (dry season, closed circle, -) of 2008 in saplings of forest tree species of the Central Amazon. Experimental conditions as described in Figure 5. Each symbol represents one leaf (one or two leaves per plant). **significant at $p<0.01$.

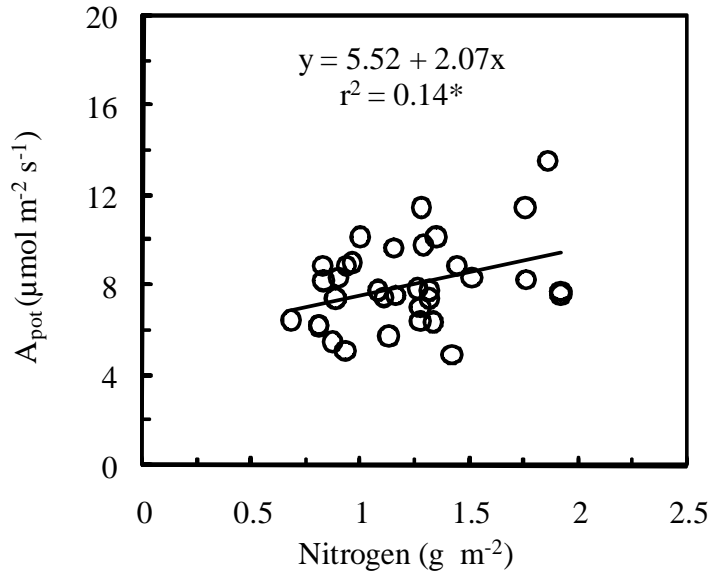

Figure 9 - Relationship between photosynthetic capacity $\left(\mathrm{A}_{\text {pot }}\right)$ and leaf nitrogen content in January (wet season) of 2008 in saplings of ten forest tree species of the Central Amazon. Experimental conditions as described in Figure 5. Each symbol represents one leaf (one or two leaves per plant). *significant at $p<0.05$.

the dry season of 2008 was not strong enough to unambiguously negate any potential effect of rainfall seasonality on the photosynthetic capacity of saplings. Further studies are needed to elucidate how a prolonged dry season may affect the diurnal pattern of photosynthesis, Rubisco activity, and electron transport rates, which may ultimately affect tree growth in the Central Amazon. Finally, even though irradiance in the forest floor is usually very low, it remarkably affects leaf physiology and leaf anatomy, as photosynthetic capacity, LT and SLA responded to variations in the fraction of sky visible in the forest understory.

\section{Acknowledgements}

To the Ministry of Science and Technology MCT/ INPA, FAPEAM (project PIPT-1746-08), CAPES and CNPq.

\section{References}

Coley, P.D. 1988. Effects of plant growth rate and leaf lifetime on the amount and type of anti-herbivore defense. Oecologia 74: 531-536.

Cox, P.M.; Betts, R.A.; Collins, M.; Harris, P.P.; Huntingford, C.; Jones, C.D. 2004. Amazonian forest dieback under climatecarbon cycle projections for the 21st century. Theoretical and Applied Climatology 78: 137-156.

Denslow, J.S.; Schultz, J.C.; Vitousek, P.M.; Strain, B.R. 1990. Growth responses of tropical shrubs to treefall gap environments. Ecology 71: 165-179.

Doughty, C.E.; Goulden, M.L.; Miller, S.D.; Rocha, H.R. 2006. Circadian rhythms constrain leaf and canopy gas exchange in an Amazonian forest. Geophysical Research Letters 33: 1-5 (L15404, DOI 10.1029/2006GL026750).

Ellsworth, D.S.; Reich, P.B. 1993. Canopy structure and vertical patterns of photosynthesis and related leaf traits in a deciduous forest. Oecologia 96: 169-178. 
Flexas, J.; Medrano, H. 2002. Drought-inhibition of photosynthesis in $C_{3}$ plants: stomatal and non-stomatal limitations revisited. Annals of Botany 89: 183-189.

Flexas, J; Bota, J., Escalona, J.M.; Sampol, B.; Medrano, H. 2002. Effects of drought on photosynthesis in grapevines under field conditions: an evaluation of stomatal and mesophyll limitations. Functional Plant Biology 29: 461-471

Gorton, H.L.; Williams, W.E.; Assmann, S.M. 1993. Circadian rhythms in stomatal responsiveness to red and blue-light. Plant Physiology 103: 399-406.

Habermann, H.M. 1973. Evidence for two photoreactions and possible involvement of phytochrome in light-dependent stomatal opening. Plant Physiology 51: 543-548.

Hikosaka, K. 2004. Interspecific difference in the photosynthesisnitrogen relationship: patterns, physiological causes, and ecological importance. Journal of Plant Research 117: 481-494.

Hikosaka, K. 2005. Nitrogen partitioning in the photosynthetic apparatus of Plantago asiatica leaves grown under different temperature and light conditions: similarities and differences between temperature and light acclimation. Plant and Cell Physiology 46: 1283-1290.

Holmes, M.G.; Klein, W.H. 1986. Photocontrol of dark circadian rhythms in stomata of Phaseolus vulgaris L. Plant Physiology 82: 28-33.

Huete, A.R.; Didan, K.; Shimabukuro, Y.E.; Ratana, P.; Saleska, S.R.; Hutyra, L.R.; Yang, W; Nemani, R.R.; Myneni, R. 2006. Amazon rainforests green-up with sunlight in dry season. Geophysical Research Letters 33: 1-4 (L06405. DOI:10.1029/ 2005GL025583).

Hughes, L. 2000. Biological consequences of global warming: is the signal already apparent? Trends in Ecology and Evolution 15: 56-61.

Instituto Nacional de Meteorologia [INMET]. 2008. Climate. Available at: http://www.inmet.gov.br/clima. [Accessed Nov. 15, 2008].

Kaiser, H.; Kappen, L. 2000. In situ observation of stomatal movements and gas exchange of Aegopodium podagraria L. in the understorey. Journal of Experimental Botany 51: 1741-1749.

Kruger, E.L.; Volin, J.C. 2006. Reexamining the empirical relation between plant growth and leaf photosynthesis. Functional Plant Biology 33: 421-429.

Kursar, T.A.; Coley, P.D. 1999. Contrasting modes of light acclimation in two species of the rainforest understory. Oecologia 121: 489-498.

Lee, D.W.; Oberbauer, S.F.; Johnson, P.; Krishnapilay, B.; Mansor, M.; Mohamad, H.; Yap, S.K. 2000. Effects of irradiance and spectral quality on leaf structure and function in seedlings of two Southeast Asian Hopea (Dipterocarpaceae) species. American Journal of Botany 87: 447-455.

Lewis, S.L.; Malhi, Y.; Phillips, O.L. 2004. Fingerprinting the impacts of global change on tropical forests. Philosophical Transactions of the Royal Society of London 359: 437-462.

Machado, E.C.; Medina, C.L.; Gomes, M.M.A.; Habermann, G. 2002. Seasonal variation of photosynthetic rates, stomatal conductance and leaf water potential in 'Valencia' orange trees. Scientia Agricola 59: 53-58 (in Portuguese, with abstract in English).

Marenco, R.A.; Siebke, K.; Farquhar, G.D.; Ball, M.C. 2006. Hydraulically based stomatal oscillations and stomatal patchiness in Gossypium hirsutum. Functional Plant Biology 33: 1103-1113.

Marenco, R.A.; Vieira, G. 2005. Specific leaf area and photosynthetic parameters of tree species in the forest understorey as a function of the microsite light environment in Central Amazonia. Journal of Tropical Forest Science 17: 265278.

McMillen, G.G.; McClendon, J.H. 1983. Dependence of photosynthetic rates on leaf density thickness in deciduous woody plants grown in sun and shade. Plant Physiology 72: 674-678.
Molion, L.C.B. 1987. Micrometeorology of an Amazonian rain forest. p. 255-272. In: Dickinson, R.E, ed. The geophysiology of Amazonia: vegetation and climate interactions. John Wiley, New York, NY, USA.

Nepstad, D.C.; Carvalho, C.R.; Davidson, E.A.; Jipp, P.H.; Lefebvre, P.A.; Negreiros, G.H.; Silva, E.D.; Stone, T.A.; Trumbore, S.E.; Vieira, S. 1994. The role of deep roots in the hydrological and carbon cycles of Amazonian forests and pastures. Nature 372: 666-669.

Nepstad, D.C.; Tohver, I.M.; Ray, D.; Moutinho, P.; Cardinot, G. 2007. Mortality of large trees and lianas following experimental drought in an Amazon forest. Ecology 88: 2259-2269.

Niinemets, U. 1999. Research review components of leaf dry mass per area: thickness and density; alter leaf photosynthetic capacity in reverse directions in woody plants. New Phytologist 144: 35-47.

Oguchi, R.; Hikosaka, K.; Hirose, T. 2005. Leaf anatomy as a constraint for photosynthetic acclimation: differential responses in leaf anatomy to increasing growth irradiance among three deciduous trees. Plant, Cell and Environment 28: 916-927.

Oyama, M.D.; Nobre, C.A. 2003. A new climate-vegetation equilibrium state for Tropical South America. Geophysical Research Letters 30: 1-4 (DOI:10.1029/2003GL018600).

Park, S.Y.; Furukawa, A. 1999. Photosynthetic and stomatal responses of two tropical and two temperate trees to atmospheric humidity. Photosynthetica 36: 181-186.

Peeters, P.J. 2002. Correlations between leaf structural traits and the densities of herbivorous insect guilds. Biological Journal of the Linnean Society 77: 43-65.

Poorter, L.; Oberbauer, S.F. 1993. Photosynthetic induction responses of two rain-forest tree species in relation to light environment. Oecologia 96: 193-199.

Reich, P.B.; Ellsworth, D.S.; Walters, M.B. 1998. Leaf structure (specific leaf area) modulates photosynthesis-nitrogen relations: evidence from within and across species and functional groups. Functional Ecology 12: 948-958.

Saleska, S.R.; Didan, K.; Huete, A.R.; Da Rocha, H.R. 2007. Amazon forests green-up during 2005 drought. Science 318: 612612.

Shimazaki, K.I.; Doi, M.; Assmann, S.M., Kinoshita, T. 2007. Light regulation of stomatal movement. Annual Review of Plant Biology 58: 219-247.

Smith, H. 1982. Light quality, photoperception, and plant strategy. Annual Review of Plant Physiology 33: 481-518.

Turnbull, M.H. 1991. The effect of light quantity and quality during development on the photosynthetic characteristics of six Australian rainforest tree species. Oecologia 87: 110-117.

Valladares, F.; Niinemets, U. 2008. Shade tolerance, a key plant feature of complex nature and consequences. Annual Review of Ecology Evolution and Systematics 39: 237-257.

Weston, E.; Thorogood, K.; Vinti, G.; López-Juez, E. 2000. Light quantity controls leaf-cell and chloroplast development in Arabidopsis thaliana wild type and blue-light-perception mutants. Planta 211: 807-815.

Williamson, G.B.; Laurance, W.F.; Oliveira, A.A.; Delamônica, P.; Gascon, C.; Lovejoy, T.E.; Pohl, L. 2000. Amazonian tree mortality during the 1997 El Niño drought. Conservation Biology 14: 1538-1542.

Wright, I.J.; Cannon, K. 2001. Relationships between leaf lifespan and structural defences in a low-nutrient, sclerophyll flora. Functional Ecology 15: 351-359.

Yun, J.I.; Taylor, S.E. 1986. Adaptive implications of leaf thickness for sun- and shade-grown Abutilon theophrasti. Ecology 67: 13141318.

Received March 05, 2009

Accepted June 14, 2010 